\title{
MODERN APPROACH TO THE THERAPY OF INFECTIONS CAUSED BY CLOSTRIDIUM DIFFICILE
}

\author{
Saša Jaćović ${ }^{1}$, Slobodan Milisavljević ${ }^{2}$, Miloš Milosavljević ${ }^{3}$, \\ Slobodan Janković ${ }^{4}$, Srđan Stefanović ${ }^{3}$
}

${ }^{1}$ Medicines and Medical Devices Agency of Serbia, Belgrade

${ }^{2}$ Department of Surgery, Faculty of Medical Sciences, University of Kragujevac

3 Department of Pharmacy, Faculty of Medical Sciences, University of Kragujevac

${ }^{4}$ Department of Pharmacology and Toxicology, Faculty of Medical Sciences,

University of Kragujevac

\section{САВРЕМЕНИ ПРИСТУП У ТЕРАПИЈИ ИНФЕКЦИЈА ИЗАЗВАНИХ СА CLOSTRIDIUM DIFFICILE}

\section{Саша Јаћовић ${ }^{1}$, Слободан Милисављевић ${ }^{2}$, Милош Милосављевић $^{3}$, Слободан Јанковић ${ }^{4}$, Срђан Стефановић ${ }^{3}$}

${ }^{1}$ Агенција за лекове и медицинска средства Србије, Београд

2 Катедра за хирургију, Факултет медицинских наука, Универзитет у Крагујевцу

${ }^{3}$ Катедра за фрармацију, Факултет медицинских наука, Универзитет у Крагујевцу

${ }^{4}$ Катедра за фрармакологију и токсикологију, Факултет медицинских наука, Универзитет у Крагујевцу

\section{ABSTRACT}

Infection caused by Clostridium difficile (CDI) occurs as a result of imbalance of bacteria in intestinal tract mainly due to previous exposure to wide-spectrum systemic antibiotics. Nowadays, it is recognized as one of the most frequent infections acquired in hospitals. Contemporary clinicians often face an increased incidence of fulminant and recurrent CDIs that are accompanied with a number of colectomies, prolonged stay in hospitals, fatal outcome, and rising healthcare costs. Traditional antibiotics for CDI, such as metronidazole, vancomycin or fidaxomicin, have been linked to certain treatment limitations in previous studies. Thus, the aim of this narrative mini literature review was to
\end{abstract}

critically evaluate efficiency of each of the recommended modern therapy modalities for $\mathrm{CDI}$, as well as the frequency and severity of adverse events associated with their use.

Based on current knowledge, the range of standard antibiotics approved for treatment of initial or recurrent CDI remains quite limited. Regardless of severity of CDI, oral or rectal vancomycin should be considered as the first-line therapeutic option in adults and children, while fidaxomicin or metronidazole could be an appropriate alternative.The other potentially effective antimicrobials against CDI, such as rifaximin, nitazoxanide, fusidic acid, tigecyclin, bacitracin and use of probiotics cannot be advised as the therapy of choice, as they did not provide any advantage over vancomycin or fidaxomicin in

Контакm: Milosavljević Miloš,

Faculty of Medical Sciences, University of Kragujevac, Svetozara Markovića 69

e-mail: milosavljevicmilos91@gmail.com 
prior investigations. In an attempt to solve the problem of recurrent CDI events, which is one of the most important challenges facing health professionals today, adjunct use of human monoclonal antibody against toxin B (bezlotoxumab) or instillation of normal colonic bacteria obtained from healthy donor into patient's intestine (Fecal Microbiota Transplantation), could be effective and safe approach where available. Besides clinical development of innovative therapy for CDI, such as new antibiotics and vaccines, primary focus should be on effective prevention of this infection, in terms of improving rational use of broad-spectrum systemic antibiotics and proton pump inhibitors.

Keywords: clostridium difficile, vancomycin, fidaxomicin, metronidazole, bezlotoxumab, fecal microbiota transplant.

\section{САЖЕТАК}

Колитис узрокован бактеријом Clostridium difficile (CDC) настаје као резултат поремећаја равнотеже бактерија у гастроинтестиналном тракту, углавном због претходне системске примене антибиотика широког спектра дејства. У данашње време ова врста колитиса представља једну од најучесталијих инфекција стечених у болничкој средини. При томе, данас се клиничари често суочавају са растућом инциденцијом фулминантних и рекурентних $\mathrm{CDC}$, који су праћени бројним колектомијама, продуженим бораваком у болници, фаталним исходом и повећањем свеукупних трошкова здравствене заштите. Традиционални антибиотици за лечење CDCa, попут метронидазола, ванкомицина или фидаксомицина, у претходним истраживањима показали су одређене терапијске недостатке. Стога је циљ овог наративног ревијалног рада био да се критички процени ефикасност сваког од препоручених лекова заCDC, као и учесталост и озбиљност нежељених догађаја који прате њихову примену.

На основу актуелних сазнања, дијапазон стандардних антибиотика одобрених за лечење иницијалне или рекурентне CDC прилично је ограничен. Без обзира на тежину $\mathrm{CDC}$, орални или ректални ванкомицин данас се сматра терапијском опцијом прве линије код одраслих, док фидаксомицин или метронидазол представљају одговарајуће алтернативе. С друге стране, метронидазол је лек избора за лечење иницијалне и прве рекурентне епизоде CDC у дечијој популацији. Други потенцијално ефикасни антимикробни леко- виза CDC, попут рифаксимина, нитазоксанида, фусидинске киселина, тигециклина, бацитрацина, као и употреба пробиотика, не могу се препоручити као терапија избора с обзиром да у претходним истраживањима у погледу клиничких ефеката нису показали никакве предности у односу на ванкомицин или фидаксомицин. У покушају да се реши проблем рекурентних CDC догађаја, што је један од најважнијих изазова са којима се данас срећу здравствени радници, додатна употреба хуманог моноклонског антитела против токсина Б СD (без лотоксумаб) уз стандардни начин лечења или инфузија суспензије фецеса здравих донора у дебело црево пацијента (фекална трансплантација), могу бити ефикасан и безбедан терапијски приступ у ситуацијама где су такве процедуре доступне. До завршетка клиничког развоја иновативне терапије за CDC, попут нових антибиотика и вакцина против Clostridium difficile, примарни фокус треба да буде на ефикасној превенцији ове инфекције, у смислу унапређења рационалне употребе системских антибиотика широког спектра дејства и инхибитора протонске пумпе.

Кључне речи: clostridium difficile, ванкомицин, фидаксомицин, метронидазол, безлотоксумаб, фекалнатрансплантација.

\section{INTRODUCTION}

Clostridium difficile infection (CDI) results from alteration of normal colonic microflora mainly due to previous exposure to broad-spectrum antibiotics. This intestinal dysbiosis leads to colonization with $\mathrm{CD}$ which releases the toxins that cause harmful mucosal and systemic effects. CDI clinically manifests with various disorders in terms of severity, starting from diarrhea through fulminant forms of colitis ${ }^{1,4}$.

The epidemiology and clinical feature of CDI has changed significantly over past 20-30 years. Worldwide, $\mathrm{CD}$ is now the most common cause of nosocomial diarrhea. Besides, nowadays clinicians face CDI accompanied with increasing incidence of severe and complicated disease, recurrence rates, colectomies, lengths of hospital stay, and deaths ${ }^{1-4}$. These problems are probably due to growing prevalence of major factors that contribute to the appearance of CDI, like ageing of the population, irrational usage of antibiotics, emergence of epidemic, hyper virulent strains of $\mathrm{CD}$ and widespread use of proton pump inhibitors ${ }^{1,3-5}$. However, infection caused by Clostridium difficile is not only being diagnosed in 
patients in long-term care facilities or in hospitals who often get exposed to inappropriate antibiotic therapy. An increasing number of CDIs occur in populations that have previously been considered to have a low risk of occurrence of CDI, such as pregnant women or young healthy persons ${ }^{1,3,4}$. Anyway, it is quite clear that this infection today poses an important additional medical and financial burden on contemporary health care systems and societies in general.

Recommendations for treatment of CDIs are based on the assessment of disease severity, local epidemiology, type of $\mathrm{CD}$ strains presented as well as whether it is an initial or recurrent infection. Antibiotics for CDI treatment (vancomycin, metronidazole or fidaxomicin), although widely accepted as traditional first line therapy, have certain treatment limitations ${ }^{1,3-6}$. Therefore, in terms of improving health outcomes some complementary therapeutic modalities were suggested, including instillation of normal colonic bacteria obtained from healthy donor into patient's intestine, i.e. Fecal Microbiota Transplantation (FMT) and use of targeted passive immunotherapy with bezlotoxumab ${ }^{1,3-7}$. In addition, there are a few promising innovative ventures that are currently being clinically developed, such as active immunization with chemically and/or genetically modified vaccines against $C D$ toxins $^{8-10}$ as well as some other novel narrowspectrum antibiotics (cadazolid, surotomycin, ridinilazole, etc.) that have an inhibitory effect on formation of $\mathrm{CD}$ spores and an advantageous pharmacokinetic and pharmacodynamic (PK/PD) feature to treat $\mathrm{CDIs}^{5}$. However, despite these recent therapeutic advances judicious use of wide-spectrum antibiotics probably still remains the most effective preventive strategy within overall management of CDI.

In this narrative mini literature review we made an attempt to critically evaluate each of previously mentioned modern treatment modalities in terms of efficacy and safety, based on available clinical data.

\section{ANTIMICROBIAL THERAPY OF CDI}

The wide-spectrum antibiotics such as metronidazole (oral or intravenous formulation) or vancomycin (oral formulation), have been considered as a cornerstone of treatment of the initial episode or subsequent relapse or reinfection throughout past decades. The usual dose of vancomycin for the treatment of CDI is $125 \mathrm{mg} 4$ times daily for 10 days in adults and $10 \mathrm{mg} / \mathrm{kg} 3$ or 4 times daily for 10 days in children, while the usual dose of metronidazole for the treatment of $\mathrm{CDI}$ is $500 \mathrm{mg} 3$ times daily for 10 days in adults and $7.5 \mathrm{mg} / \mathrm{kg} 3$ or 4 times daily for 10 days in children ${ }^{1}$. Besides, fidaxomicin as an antimicrobial drug with narrow-spectrum of activity (thus alters intestinal microflora to much less extent than metronidazole and vancomycin do) and favorable PK/PD profile, was recently approved worldwide and also suggested as an alternative to vancomycin for initial therapy of more serious forms of CDI in adults as well as for treating recurrent episodes, particularly in patients with high risk of getting CDI again ${ }^{1,3,6,11-14}$. However, based on recent relevant randomized trial and observational data, metronidazole appears to be less effective then vancomycin in terms of attaining initial and sustained clinical response in adult patients with CDI, especially when treating severe episode ${ }^{1,6,11,13-15}$. Furthermore, it seems that both of these antibiotics are not essentially efficacious as fidaxomicin is with respect to the control of CD spreading and prevention of relap$\mathrm{se}^{16,17}$. In previous studies, the safety of each mentioned antimicrobial therapy was relatively good, exceptionally implying potential irreversible neurotoxicity during long-term and repeated administration of metronidazole as well as the emergence of infections caused by resistant strains of Enterococci after use of vacomycin, and to a lesser extent after use of metronidazol or fidaxomicin ${ }^{1}$. In fact, relatively small differences in clinical effects of these antibiotics were observed so far $^{13}$ emphasizing the importance of adequate assessment of their cost-effectiveness in a particular settings, taking into account that metronidazole is by far the cheapest antibiotic among them. Nevertheless, in the light of the aforementioned, the latest official guideline for the treatment of CDI does not advise the use of metronidazole as the first-line monotherapy neither for initial episode of non-severe CDI in adult population,nor as the treatment of first recurrence, due to lower effectiveness compared to vancomycin or fidaxomicin. In this updated guideline, oral metronidazole remained as an alternative therapy for treatment in adults with initial non-severe form of CDI when vancomycin or fidaxomicin are unavailable or contraindicated (in a dose of $500 \mathrm{mg} 3$ times daily for 10 days), while in fulminant cases, complicated particularly with ileus, parenteral metronidazole has been suggested together with the rectal vancomycin ${ }^{1}$. Finally, due to paucity of novel clinical evidence in children,metronidazol continues to be advised as an alternative to vancomycin as the first choice monotherapyfor 
treatment of non-severe CDI episode (in a dose of $7.5 \mathrm{mg} / \mathrm{kg} 3$ or 4 times daily) ${ }^{1}$. An interesting issue regarding the changes in these updated recommendations is the involvement of fidaxomicin as an alternative option to vancomycin for the treatment of initial as well as for the first and especially for the multiple recurrent CDIs events in adults, respectively. Fidaxomicin is the most expensive antibiotic among those suggested for the first-line therapy of CDI (in a dose of 200 mg 2 times daily for 10 days) and offers the advantages over vancomycin in terms of efficacy that are not clearly evident based on previous studies ${ }^{1,13,14}$. Therefore, despite the largest acquisition cost, in our opinion, fidaxomicin can be administered only as the first-choice therapy for different forms of CDI after its cost-effectiveness was unequivocally demonstrated in a particular indication at the national level in countries with a sufficiently large cost-effectiveness threshold. The latter is supported by the evidence from systematic review of economic evaluation of antimicrobial therapy for CDI by Burton HE et al, indicating that fidaxomicin could have a better cost-effectiveness ratio then other antibiotics for CDI treatment in patients with highrisk of complicated and recurrent CDI, when the majority of pharmacoeconomic outcomes were taken into account ${ }^{18}$. As an example, the study that was carried out in Serbia, a country passing throughout socioeconomic transition where the fidaxomicin has not been approved yet, suggests this drug could be more cost-effective option in patients refractory to metronidazole monotherapy in comparison to vancomycin, since it saves more lives, but does not avoid colectomies; this comparative advantage could be especially obvious in patients with the recurrent infection that must continue to use systemic antibiotics, particularly if free-market prices of health services in Serbia are allowed ${ }^{19}$.

The other additional antimicrobial treatment options, such as rifaximin, nitazoxanide, fusidic acid, tigecyclin, bacitracin and use of probiotics appeared to be potentially effective in some prior studies, but currently there are no valid clinical studies whose results would recommend their use as the first-choice therapy for CDI, considering they do not provide any advantages over vancomycin or fidaxomicin regarding efficacy and safety ${ }^{1}$.

\section{BEZLOTOXUMAB}

Bezlotoxumab is a fully human monoclonal antibody against cytotoxin (toxin B) produced by CD. This drug was recently approved in United States of America (USA) and European Union (EU) as an adjunctive therapy to standard care in an attempt to overcome the major shortcoming of antibiotic treatment in terms of prevention of recurrent CDI events ${ }^{7}$. Thus, bezlotoxumab should be administered once at a dose of $10 \mathrm{mg} / \mathrm{kg}$ in the form of adjuvant therapy to basic antibiotic therapy in adult patients who are at risk of recurrent infection ${ }^{7}$.

In two pivotal double-blinded, randomized controlled clinical trials (MODIFY I and MODIFY II) that had been carried out inmore than 2600 patients, bezlotoxumab was superior to placebo concerning significant reduction of recurrent CDI events at 12 weeks after infusion ${ }^{7}$. At the same time, similar and quite acceptable overall safety of both treatments was observed ${ }^{7}$. The addition of actoxumab (human monoclonal antibody against $\mathrm{CD}$ toxin $\mathrm{A}$ ) did not result in enhanced effectiveness of bezlotoxumab ${ }^{7}$. After additional analysis of aggregatedata from MODIFY I and II studies, based on stratification of risk for recurrence, bezlotoxumab showed not onlysignificant reduction of recurrent events, but also FMT was used to a lesser degree and lower readmission rate to hospital at 30 days due to CDI was registered in comparison to placebo ${ }^{20}$. Taking into account the latter results, it was recommended that patients who have 3 or more risk factors for recurrent CDI can benefit most from adding bezlotoxumab to standard antibiotic treatment, and this could also be useful for those with fewer risk factors ${ }^{20}$. However, this shortlived protective effect of bezlotoxumab requires further investigations that would deal with its possible long-term positive influence on incidence of recurrent CDIs.

Rare but serious adverse event after use of bezlotoxumab observed in the aforementioned clinical trials was an exacerbation of heart failure $^{21,22}$. Exacerbation of heart failure was more frequent in group of congestive heart failure patients who received bezlotoxumab than in similar patients treated with placebo $(12.7 \%$ : $4.9 \%$ ) and led to higher death rate in the bezlotoxumab group ${ }^{21,22}$. However, far more precise data on such adverse event will probably come from upcoming post-marketing observational studies, since the bezlotoxumab has been approved in 2017. Until then, bezlotoxumab sho- 
uld be used cautiously in patients with underlying chronic heart failure.

\section{FECAL MICROBIOTA TRANSPLANTATION}

In order to reverse the perturbation of normal gut flora caused by repetitive use of antibiotics to treat CDI, transfer of processed stool gathered up from healthy individual to digestive tract of patients has being strongly recommended as the highly efficient therapy for multiple recurrent CDI events in cases that became resistant to previous administration of standard antibiotics for $\mathrm{CDI}^{1,6}$. For the first time, FMT had been clinically applied in USA in 2003, and after that across the world it was advised to be implemented in clinical practice for the therapy of recurrent CDI episodes both in adults and children regardless of its severity as well as for the refractory recurrent cases ${ }^{1,23}$. FMT can be administered via infusion of stool into colon by colonoscopy, sigmoidoscopy and enema, or into upper gastrointestinal tract by nasogastric/ nasoduodenal tube and upper endoscopy as well as by mouth in the form of capsules containing lyophilized material obtained from a donor ${ }^{24}$.

A plenty of literature reports on high efficacy rate of FMT in reconstitution of colonic microbiota leading to successful treatment of recurrent CDI of up to over $90 \%$ exist so $\operatorname{far}^{25-32}$. In the first published un-blinded randomized controlled trial conducted in the group of patients who had two or more recurrent episodes of CDI, FMT demonstrated superiority to oral vancomycin with and without bowel lavage, in terms of approximately 3 times greater chance to achieve sustained relief of CDI symptoms at 10 weeks after completion of therapy ${ }^{25}$. However, the data from randomized trials mostly indicate higher efficacy rate than the information obtained from nonrandomized investigations. It was shown that FMT had been more efficient when transferred in the colon than via an upper gastrointestinal tract approach $^{25-28,30,31}$, when multiple treatment courses had been applied ${ }^{1,33}$ and if the patient did not suffer from inflammatory bowel disease ${ }^{34}$. Besides, the response to FMT can also be affected by selection of donors and patients, composition of final product applied, assessed likelihood of recurrence and prior antibiotic therapy ${ }^{1}$. Therefore, a few relevant challenges continue to exist with respect to implementation of FMT in routine clinical practice ${ }^{24}$. First of all, methods of processing stool collected from community dwelling donors as well as procedures of FMT administration can be quite different. The other obstacles include unreliability and uncertainty of optimal dose regimen of FMT related to expected therapeutic response, especially when fulminant cases with CDI are being treated. Finally, the costs of treatment usually overcome insurance reimbursed costs. For example, in EU or Australia or China, FMT has not been regulated as a drug yet, while in USA and Canada this biological product is considered as an investigational therapeutic option, requiring permissions before each its use as a part of clinical trial ${ }^{24}$. In addition, the safety profile of FMT has not been particularly studied in clinical trials with large samples and sufficient follow up so far, but potentially serious adverse events, such as gastrointestinal bleeding and perforation after nasogastric/nasoenteric tube or colonoscopy insertions as well as complications due to infection transmission were very rarely reported ${ }^{1}$. In spite of increasing demand for FMT in recent years, all mentioned facts currently constrain widespread clinical use of this potentially the most efficacious therapeutic approach for treatment of recurrent CDI in adult population and children to date.

\section{CONCLUSIONS}

Based on current state-of-art the range of standard antibiotics for treatment of initial or recurrent CDI is quite limited. Oral or rectal vancomycin should be considered as the first-line therapeutic option in adults and children, while fidaxomicin or metronidazole could be an adequate alternative. In an attempt to solve the problem of recurrent CDI events, which is one of the most important challenges facing health professionals today, adjunct use of bezlotoxumab or FMT could be effective and safe approach where available.

However, besides clinical development of innovative therapy for CDI, such as new antibiotics and vaccines, primary focus should be on effective prevention of this infection, in terms of improving rational use of broad-spectrum systemic antibiotics and proton pump inhibitors.

\section{ACKNOWLEDGEMENTS}

We are thankful to Serbian Ministry of Education for funding this article by the Grant No 175007. 


\section{REFERENCES}

1. McDonald LC, Gerding DN, Johnson S, et al. Clinical Practice Guidelines for Clostridium difficile Infection in Adults and Children: 2017 Update by the Infectious Diseases Society of America (IDSA) and Society for Healthcare Epidemiology of America (SHEA). Clin Infect Dis 2018; 66(7): e1-e48.

2. European Centre for Disease Prevention and Control. European Centre for Disease Prevention and Control. Clostridium difficile infections. In: ECDC. Annual epidemiological report for 2016. Stockholm: ECDC; 2018.

3. Vindigni SM, Surawicz CM. C. difficile Infection: Changing Epidemiology and Management Paradigms. ClinTranslGastroenterol 2015; 6:e99.

4. Evans CT, Safdar N. Current Trends in the Epidemiology and Outcomes of Clostridium difficile Infection. Clin Infect Dis 2015; 60 Suppl 2: S66-71.

5. Petrosillo N, Granata G, Cataldo MA. Novel Antimicrobials for the Treatment of Clostridium difficile Infection. Front Med (Lausanne) 2018; 5: 96.

6. Kociolek LK, Gerding DN. Breakthroughs in the treatment and prevention of Clostridium difficile infections. Nat Rev GastroenterolHepatol 2016; 13: 150-60.

7. Wilcox MH, Gerding DN, Poxton IR, et al; MODIFY I and MODIFY II Investigators. Bezlotoxumab for prevention of recurrent Clostridium difficile infection. $\mathrm{N}$ Engl J Med 2017; 376: 305-17.

8. de Bruyn G, Saleh J, Workman D, et al; H-030-012 Clinical Investigator Study Team. Defining the optimal formulation and schedule of a candidate toxoid vaccine against Clostridium difficile infection: A randomized phase 2 clinical trial. Vaccine 2016; 34: 2170-8.

9. Sheldon E, Kitchin N, Peng Y, et al. A phase 1, placebo-controlled, randomized study of the safety, tolerability, and immunogenicity of a Clostridium difficile vaccine administered with or without aluminum hydroxide in healthy adults. Vaccine 2016; 34: 2082-91.

10. Bezay N, Ayad A, Dubischar K, et al. Safety, immunogenicity and dose response of VLA84, a new vaccine candidate against Clostridium difficile, in healthy volunteers. Vaccine 2016; 34: 2585-92.

11. Debast SB, Bauer MP, Kuijper EJ. European society of clinical microbiology and infectious diseases: update of the treatment guidance document for Clostridium difficile infection. ClinMicrobiol Infect 2014; 20(Suppl 2): $1-26$.

12. Trubiano JA, Cheng AC, Korman TM, et al. Australasian society of infectious diseases updated guidelines for the management of Clostridium difficile infection in adults and children in Australia and New Zealand. Intern Med J 2016; 46(4): 479-93.

13. Nelson RL, Suda KJ, Evans CT. Antibiotic treatment for Clostridium difficile-associated diarrhoea in adults. Cochrane Database Syst Rev 2017; 3:CD004610.

14. Ooijevaar RE, van Beurden YH, Terveer EM, et al. Update of treatment algorithms for Clostridium difficile infection. ClinMicrobiol Infect 2018; 24(5): 452-62.

15. Di X, Bai N, Zhang X, et al. A meta-analysis of metronidazole and vancomycin for the treatment of Clostridium difficile infection, stratified by disease severity. Braz J Infect Dis 2015; 19(4): 339-49.

16. Babakhani F, Bouillaut L, Gomez A, Sears P, Nguyen L, Sonenshein AL. Fidaxomicin inhibits spore produc- tion in Clostridium difficile. Clin Infect Dis 2012; 55(Suppl 2): S162-9.

17. Biswas JS, Patel A, Otter JA, et al. Reduction in Clostridium difficile environmental contamination by hospitalized patients treated with fidaxomicin. J Hosp Infect 2015; 90(3): 267-70.

18. Burton HE, Mitchell SA, Watt M. A Systematic Literature Review of Economic Evaluations of Antibiotic Treatments for Clostridium difficile Infection. Pharmacoeconomics 2017; 35(11): 1123-40.

19. Marković V, Kostić M, Iličković I, Janković SM. CostEffectiveness Comparison of Fidaxomicin and Vancomycin for Treatment of Clostridium difficile Infection: A Markov Model Based on Data from a South West Balkan Country in Socioeconomic Transition. Value Health Reg Issues 2014; 4: 87-94.

20. Gerding DN, Kelly CP, Rahav G, et al. Bezlotoxumab for prevention of recurrent $C$. difficile infection in patients at increased risk for recurrence. Clin Infect Dis 2018. doi: 10.1093/cid/ciy171. [Epub ahead of print]

21. Navalkele BD, Chopra T. Bezlotoxumab: an emerging monoclonal antibody therapy for prevention of recurrent Clostridium difficile infection. Biologics: Targets \& Therapy 2018; 12: 11-21.

22. Lee Y, Lim WI, Bloom CI, Moore S, Chung E, Marzella N. Bezlotoxumab (Zinplava) for Clostridium Difficile Infection: The First Monoclonal Antibody Approved to Prevent the Recurrence of a Bacterial Infection. Pharmacy and Therapeutics 2017; 42(12): 735-8.

23. Cammarota G, Ianiro G, Tilg H, et al; European FMT Working Group. European consensus conference on faecalmicrobiota transplantation in clinical practice. Gut 2017; 66(4): 569-580.

24. Kelly BJ, Tebas P. Clinical Practice and Infrastructure Review of Fecal Microbiota Transplantation for Clostridium difficile Infection. Chest 2018; 153(1): 266-77.

25. van Nood E, Vrieze A, Nieuwdorp M, et al. Duodenal infusion of donor feces for recurrent Clostridium difficile. N Engl J Med 2013; 368: 407-15.

26. Brandt LJ, Aroniadis OC, Mellow M, et al. Long-term follow-up of colonoscopic fecal microbiota transplant for recurrent Clostridium difficile infection. Am J Gastroenterol 2012; 107: 1079-87.

27. Hamilton MJ, Weingarden AR, Sadowsky MJ, Khoruts A. Standardized frozen preparation for transplantation of fecal microbiota for recurrent Clostridium difficile infection. Am J Gastroenterol 2012; 107: 761-7.

28. Cammarota G, Masucci L, Ianiro G, et al. Randomised clinical trial: faecal microbiota transplantation by colonoscopy vs. vancomycin for the treatment of recurrent Clostridium difficile infection. Aliment PharmacolTher 2015; 41: 835-43.

29. Youngster I, Sauk J, Pindar C, et al. Fecal microbiota transplant for relapsing Clostridium difficile infection using a frozen inoculum from unrelated donors: a randomized, open-label, controlled pilot study. Clin Infect Dis 2014; 58: 1515-22.

30. Lee $\mathrm{CH}$, Steiner T, Petrof EO, et al. Frozen vs fresh fecal microbiota transplantation and clinical resolution of diarrhea in patients with recurrent Clostridium difficile infection: a randomized clinical trial. JAMA 2016; 315: 142-9.

31. Kelly CR, Khoruts A, Staley C, et al. Effect of fecal microbiota transplantation on recurrence in multiply 
recurrent Clostridium difficile infection: a randomized trial. Ann Intern Med 2016; 165: 609-16.

32. Rubin TA, Gessert CE, Aas J, Bakken JS. Fecal microbiome transplantation for recurrent Clostridium difficile infection: report on a case series. Anaerobe 2013; 19: 22-6.

33. Weingarden AR, Hamilton MJ, Sadowsky MJ, Khoruts A. Resolution of severe Clostridium difficile infection following sequential fecal microbiota transplantation. J ClinGastroenterol 2013; 47(8): 735-7.

34. Khoruts A, Rank KM, Newman KM, et al. Inflammatory bowel disease affects the outcome of fecal microbiota transplantation for recurrent Clostridium difficile infection. ClinGastroenterolHepatol 2016; 14: $1433-8$. 